\title{
Species diversity of Echinoderms in Manubul Island, Sulu Pro- vince, Southern Philippines
}

\author{
Shehada I. Tawasil", Ranjiv D. Alibon' \& Sophia L. Bensali' \\ ${ }^{1}$ Department of Biological Sciences, College of Science and Mathematics, Western Mindanao State University, \\ Normal Road, Baliwasan, Zamboanga City 7000, Philippines \\ ${ }^{*}$ Corresponding author, e-mail: shehadatawasil@gmail.com
}

\begin{abstract}
Echinoderms, often the most common marine organisms in the intertidal areas, are one of the target organisms in commercial fishing in Sulu Province, Southern Philippines. Proper regulation of Echinoderm harvesting requires a baseline data on its species diversity. Thus, we conducted a rapid survey of Echinoderms in the intertidal areas of Manubul Island, Sulu Province for three months to assess its species diversity using the Belt Transect Method. We identified 14 Echinoderm species through morphology-based identification with Tripneustes gratilla as the most frequently recorded species, comprising $17.94 \%$ of the total sightings. The recorded Echinoderms in Manubul Island is moderately diverse $\left(\mathrm{H}^{\prime}=2.089\right)$, possibly due to habitat heterogeneity (seagrass, mangrove, and beach ecosystems), and normal water conditions of the island (water temperature, $\mathrm{pH}$, salinity and dissolved oxygen). Although most of the identified Echinoderm species in Manubul Island are common to other areas, the island was found to be a habitat of one data deficient species (Holothuria arenicola) and one endangered species (Holothuria scabra), and this has important implications on effective regulation of Echinoderm harvesting in the island in order to protect and conserve them as well as to attain its sustainable utilization.
\end{abstract}

KEY WORDS Conservation; diversity; Echinoderms; endangered species; management plans.

Received 29.10.2020; accepted 28.12.2020; published online 26.04.2021

\section{INTRODUCTION}

Echinoderms are group of marine organisms which play functional roles in the marine ecosystems by providing essential links between unused organic materials in the detritus and larger marine organisms (Hernández et al., 2006), they also serve as predators to different benthic marine organisms (Bos et al., 2008). Moreover, some Echinoderms are of economic importance to humans such as sea cucumbers, sea urchins, and sea stars, as they are commonly consumed as food (Llacuna et al., 2016), traded as ornaments (Bos et al., 2008), and used for developing new drugs (Walag, del Rosario 2018). To date, there are approximately 7,000 Echinoderm species that are distributed worldwide in all depths in the marine ecosystems (Raghunathan, Venkataraman, 2012). The Indo-Pacific region, specifically the Philippines, hosts most of the Echinoderms species in the world (Stöhr et al., 2012). In fact, it has been identified as a hotspot of sea cucumber fisheries in Asia (Choo, 2008).

Philippines is one of the major countries which exports Echinoderms particularly sea cucumbers worldwide (Akamine, 2005). As a result, most of the Echinoderms in the country are threatened by 
overfishing especially the sea cucumbers and sea urchins (Toral-Granda et al., 2008) due to its high demand and good global prices in the market (Nievales et al., 2006; Purcell et al., 2013). This problem has already been recognized in the country through the Bureau of Fisheries and Aquatic Resources (BFAR) Administrative Order, Circular Number 248, Series of 2013, which imposed limits and requires permit to those who are engaged in the Echinoderm fishery particularly sea cucumbers trading, but the implementation is still a challenge up to this date, probably due to the lack of support from the locals and shortage of funds for enforcement (Gamboa et al., 2004).

Information concerning Echinoderms in the Philippines remains inadequate and is only limited to those commercial species, leaving the non-commercial ones unaccounted (Jontilla et al., 2014). For instance in the Southern Philippines, only few studies related to Echinoderms have been conducted in this region of the country, including but not limited to the works of Llacuna et al. (2016), Pitogo et al. (2018), Walag et al. (2018), Alibon \& Madjos (2019), Alibon \& Madjos (2020).

Sulu, an island province in the Southern Philippines, is one of the richest fishing grounds in the country with fishing as its most important industry (Mamalangkap et al., 2018), but its richness remains biologically unstudied due to the existing security threats within the province (Banlaoi 2008; Peleo 2015; United Nation 2019). Although the existing security threats in the province are favourable in freeing the area from overexploitation of the resources, the same concern had kept the locals unaware on the current conservation status of the organisms present in the area (Tabugo et al., 2013). One of the beneficial fishing grounds in Sulu Province is the island of Manubul. The inhabitants of this island are predominantly Tausug, a Muslim ethnic group currently living in Sulu Archipelago (Frake, 2006), who maintain a subsistence economy based on fishing, with Echinoderms as one of the target organisms in commercial fishing. However, if Echinoderm harvesting continues unregulated in the island, this could also increase the chances of overharvesting in the long run. Thus, this study was conducted to assess the status of Echinoderm diversity in Manubul Island, in order to support conservation and management plans as well as to attain its sustainable utilization in Sulu province, Southern Philippines.

\section{MATERIAL AND METHODS}

\section{Sampling sites and design}

The island of Manubul $\left(5^{\circ} 33^{\prime}\right.$ North, $120^{\circ} 48^{\prime}$ East), located in the province of Sulu, Southern Philippines, has a total coastal area of 94,377 hectares with 9,437.55 meters shoreline. A map of Manubul Island was obtained from the office of Department of Environment and Natural Resources-Autonomous Region of Muslim Mindanao (DENR-ARMM), Sulu, Philippines (Fig. 1), and was used as a guide to locate mangrove, sandy and settlement areas within the island. Three barangays located in this island specifically on its intertidal zones were selected as the sampling sites, namely, North Manubul, Tengah Manubul, and South Manubul. During the preliminary visit in each of the sampling site, we randomly collected 100 grams of soil samples in the intertidal areas of the island, and brought in Regional Soils Laboratory-Department of Agriculture (RSL-DA), Zamboanga City, Philippines for the substrate type analysis.

The first site is situated in the coastline of North Manubul $(5.4718,120.7968)$, a sea grass ecosystem, characterized by its gently sloping sandy coast and mostly dominated with residential houses along on its shores (Fig. 2). The second site is situated in the coastline of Tengah Manubul (5.4702, 120.7960), adjacent in a mangrove ecosystem, characterized by its thick patches of mangroves with sandy loam substrate (Fig. 3). Finally, the third site is situated in the coastline of South Manubul $(5.4667,120.7946)$, a beach ecosystem and characterized by its loamy sand shores (Fig. 4). The first and third sites are the fishing grounds of the local fishermen in the island where Echinoderms are harvested.

Sampling was done for three months (June to August, 2018). The species diversity of Echinoderms was assessed using the Belt Transect Method. In each of the three selected sampling sites, a 315 meters baseline was measured from the shoreline with a depth range of 1 to 10 meters, then three belt transects measuring 100 meters in length and five meters in width were established perpendicular to the baseline with 150 meters interval between each transect, having a total of nine surveyed transects in all sampling sites in Manubul Island. 


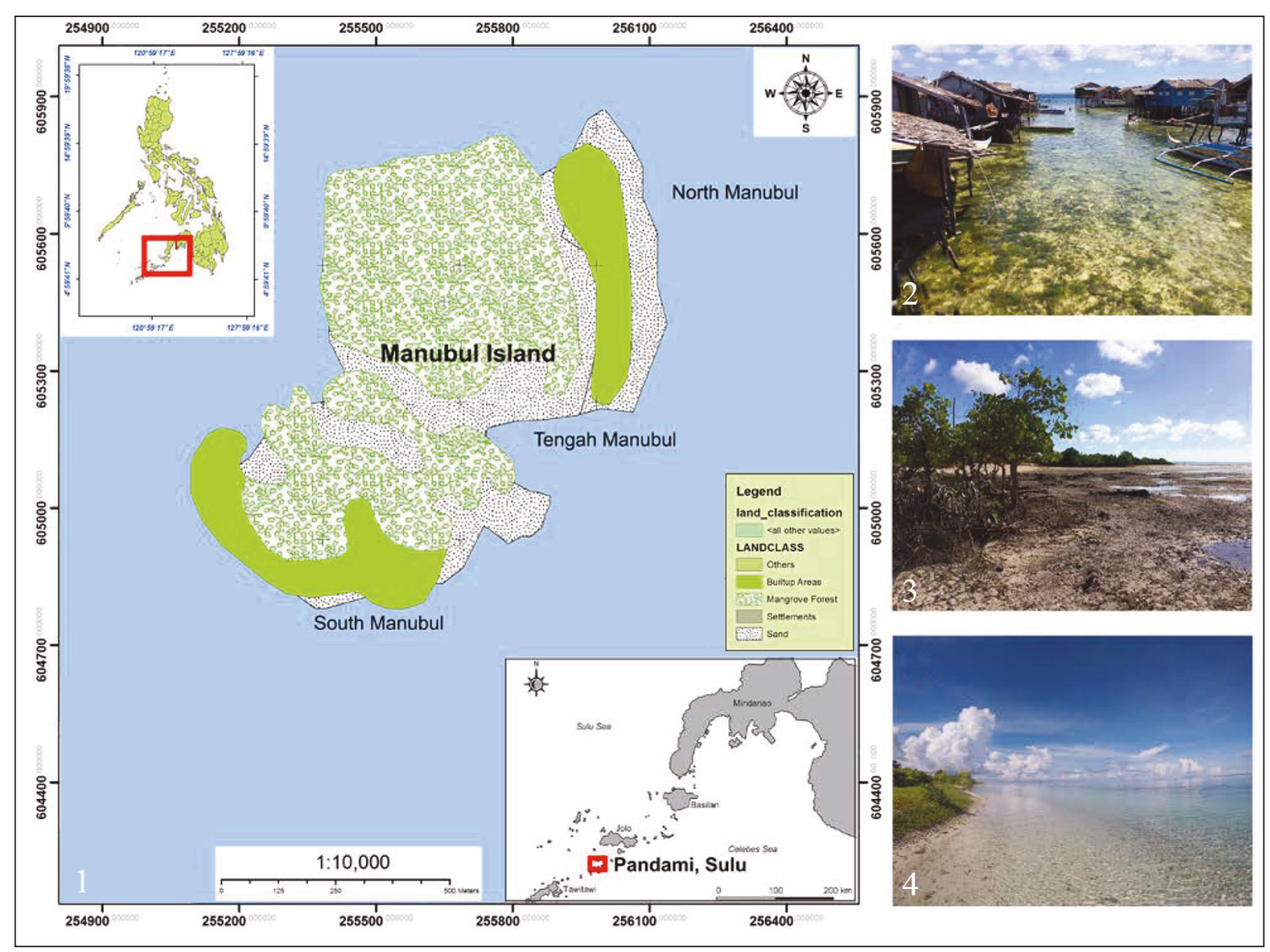

Figures 1-4. Map of Manubul Island, Sulu Province, Southern Philippines (Fig. 1) and the actual sites of North Manubul (Fig. 2), Tengah Manubul (Fig. 3) and South Manubul (Fig. 4).

Collection, preservation and identification of the samples

Direct counting of samples was done through wading and snorkelling within each transect of the three sampling sites. One to two representatives of each specimen were collected and were carefully washed with seawater to remove silt and debris. The collected samples were stored out, transferred to properly labelled containers with $10 \%$ formalin and preserved in $70 \%$ ethanol for permanent storage. Well focused and correctly exposed close-up and whole morphological features of the specimens were photographed in situ using ILCE SONY $\alpha 300020.1$ Megapixel. The collected and preserved samples were deposited in the laboratory of Department of Biological Sciences, College of Science and Mathematics, Western Mindanao State University for further identification. Samples were identified to the lowest possi- ble taxon through morphology-based identification and using a standard key reference (Schoppe, 2000; Purcell et al., 2012), subsequently the initially identified species were further validated with the help of an expert and were arranged systematically.

\section{Evaluation of the conservation status}

The identified Echinoderms species were further evaluated in terms of its conservation status based on the data provided by the International Union for Conservation of Nature (IUCN) Red List of Threatened Species or also known as the IUCN Red List. The IUCN Red List is widely recognized as the most comprehensive global approach in evaluating the conservation status of biological species. It uses a set of categories to evaluate the extinction risk of the species which include Not Evaluated, Data Deficient, Least Con- 
cern, Near Threatened, Vulnerable, Endangered, Critically Endangered, Extinct in the Wild, and Extinct.

\section{Measurement of physico-chemical parameters}

The physico-chemical parameters of the island in terms of its water conditions such as water temperature, $\mathrm{pH}$, salinity, and dissolved oxygen were monitored for three months. Three trials were obtained per belt transect in each of the sampling sites. The water temperature, $\mathrm{pH}$, and salinity were measured in situ using a digital thermometer, digital $\mathrm{pH}$ meter, and handheld salinity refractometer, respectively. In addition, one litre of water samples were brought in the laboratory of Regional Standards and Testing Laboratories-Department of Science and Technology (RSTL-DOST), Zamboanga City, Philippines for the analysis of dissolved oxygen (DO) levels using the Winkler Method.

\section{Statistical analyses}

The data on abundance of Echinoderms were used to calculate biodiversity indices which include species richness, abundance, dominance, ShannonWiener index, and evenness. Further, these data were transformed using 4th root transformation to construct a Bray-Curtis similarity index in determining the percent similarity of the Echinoderm communities through a single linkage cluster dendrogram (Murugan et al., 2016). All analyses were performed using Paleontological Statistics (PAST) Software Package version 3.17 (Hammer et al., 2001).

\section{RESULTS AND DISCUSSION}

\section{Species composition and abundance}

We recorded a total of 14 Echinoderm species in Manubul Island, Sulu Province using morphology-based identification (Fig. 6). The majority of the species belonged to class Echinodea with 5 species, and the rest of the classes (Asteroidea, Holothuridea and Ophiuroidea) were each represented with 3 species. Of the 1,873 individuals counted in the island, T. gratilla was the most fre- quently recorded species, comprising the $17.94 \%$ of the total sightings, followed by Echinothrix diadema (17.89\%), Ophiocoma scolopendrina (16.18\%), and Echinometra mathaei (16.07\%) (Fig. $5)$. The most commercially exploited sea urchin species in the Philippines is the T. gratilla (Regalado et al., 2010; Balisco 2015) which was currently found as the most abundant species in Manubul Island. Thus, the high prevalence of this species in the island may suggest that there is a low fishing pressure for this species in the island.

Based on local interviews, all identified sea cucumber species in the island (H. arenicola, H. hilla and $H$. scabra) are the most harvested Echinoderms compared to sea urchins, resulting to considerably low number of Holothuridea individuals (12.65\%) in the island. Sea cucumbers are harvested mainly for the production of trepang, a dried body wall of sea cucumber (Gamboa et al., 2004). Considering that sea cucumbers perform important ecological functions in the marine ecosystems such as increasing the nutrient levels in the water column (Grall, Chauvaud 2002), and cleaning the sediments by lowering its organic matter upon defecation (MacTavish et al., 2012), the uncontrolled harvesting of sea cucumbers in Manubul Island could lead the collapse of intertidal ecosystems (Wolkenhauer et al., 2010).

The considerably low abundance of the four Echinoderm species in the island comprising the Echinothrix calamaris $(0.37 \%)$, Ophiarachna incrassata $(0.11 \%)$, Ophiolepsis superba $(0.05 \%)$, and Pentaceraster alveolatus $(0.05 \%)$ could be habitat related, as these species usually preferred deep areas specifically in the coral reef ecosystem (Bos et al., 2008; Londoño-Cruz et al., 2018), which was not included as the sampling site in this study due to time constrains and resources. The presence of seven ubiquitous species that occurred in all sampling sites in the island namely, Linckia laevigata, Protoreaster nodosus, E. mathaei, Salmacis sphaeroides, T. gratilla, $H$. scabra, and $O$. scolopendrina may suggest its tolerance to different habitat characteristics.

\section{Conservation status}

Among the identified Echinoderm species in the island, only two species belonging to Holothuridea (H. arenicola and H. scabra) were listed on the latest information available from the IUCN Red List (Fig. 
5). H. arenicola is categorized as Data Defficient (Conand \& Gamboa, 2013), meaning this species has been categorized by the IUCN as offering insufficient information. This does not necessarily mean that the species has not been extensively studied, but rather it means that only a small number of information is available on the abundance and distribution of the species, and is not enough for a proper assessment of conservation status to be made. On the other hand, H. scabra is commercially exploited throughout its range because of its high value around the world, and because this species is estimated to have experienced at least a $50 \%$ decline over the past 30-50 years, leading to the depletion of their natural population (Akamine 2005), it is therefore categorized as Endangered (Hamel et al., 2013).

\section{Cluster analysis of Echinoderms community}

Accordingly, sites which have the same habitat characteristics and shared most of the species are the most likely to have the highest similarity (Tubelis \& Cavalcanti, 2001). This concept agrees with the result of Bray-Curtis cluster analysis of Echinoderms community (Fig. 7). For example, the three transects in North Manubul which have the highest similarity percentage of $90 \%$, possibly because of having similar type of habitat charactertistics (a sandy coast with sea grasses), resulting to similar species composition particularly the E. calamaris and $O$. superba. Further, transect 2 of Tengah Manubul was clustered to the three transects of North Manubul, having a similarity percentage of $85 \%$, due to the presence of shared species such as $H$. arenicola, $H$. hilla, and $O$. incrassata. Lowest similarity $(80 \%)$ was found between Tengah Manubul (transects 1 and 2) and other transects of different sites. This is due to the presence of Pentaceraster alveolatus which is only found in Tengah Manubul that contributed to the low percentage of similarity of this site to the other sites. Moreover, all sampling sites were clustered because of the

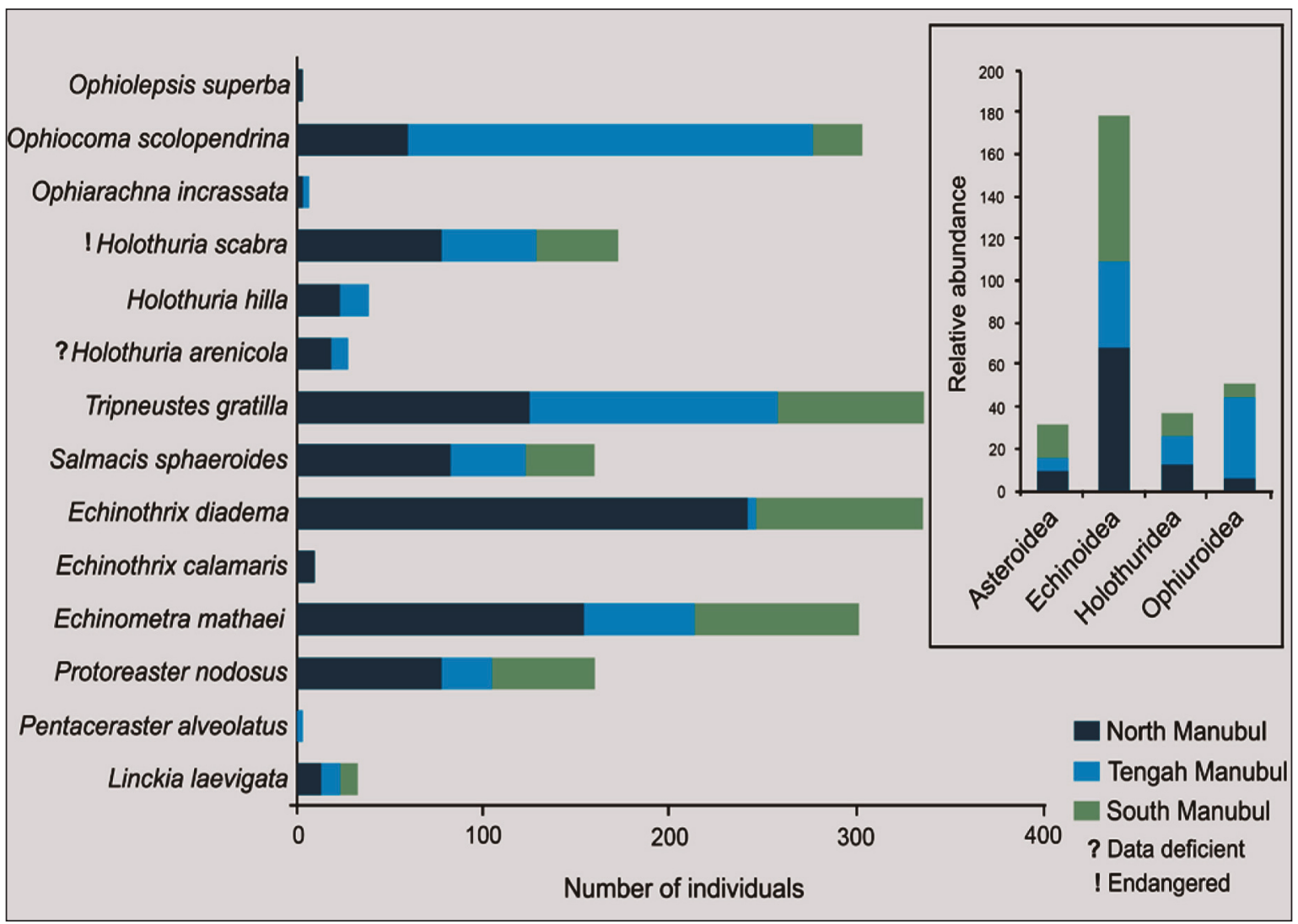

Figure 5. Echinoderm species and relative abundance of Echinoderm classes in the three sampling sites in Manubul Island, Sulu Province, Southern Philippines. 
eight ubiquitous species, namely, L. laevigata, $P$. nodosus, E. mathaei, E. diadema, S. sphaeroides, T. gratilla, $H$. scabra and $O$. scolopendrina which are present in all sampling sites.

\section{Biodiversity indices}

Among the three study sites, the most abundant (comprising the $46.93 \%$ of the total number of individuals), most species rich (12 species), and most diverse (Shannon-Weiner index $\mathrm{H}^{\prime}=2.058$ ) was the North Manubul (Table 1). This is attributed to its extensive seagrass beds that are highly productive ecosystems (Schwarz et al., 2006), and usually high in nutrient availability, enough to support the main diet for most sea urchins such as T. gratilla, E. calamaris, and $S$. sphaeroides (Yokota, 2002). Seagrass ecosystem can also reduce predation rates because of its habitat structural complexity which is preferred by sea urchins as predation can contribute to its abundance and distribution (Hereu et al., 2005). Furthermore, habitat specific cues play an important role in sea urchin larval settlement and population recruitment which seagrass beds can support (Pawlik, 1992; Hadfield \& Paul, 2001). Also, some species of sea cucumbers and sea stars prefer seagrass ecosystem because they rely heavily on it as nursery grounds and source of food from early life stages to outgrowing juveniles (Mercier et al., 2000; Bos et al., 2008; Scheibling \& Metaxas, 2010). This makes the seagrass ecosystem an important habitat of Echinoderms.

Nevertheless, the two other sites (Tengah Manubul, a mangrove ecosystem; and South Manubul, a beach ecosystem) are still considered as sites with moderate diversity, having H'values of 1.781 and 1.926, respectively. Thus, the diversity of Echinoderms in Manubul Island is moderately diverse $\left(\mathrm{H}^{\prime}=2.089\right)$ as a whole, possibly due to habitat heterogeneity in the island as evidenced by the varying habitat characteristics of the three sampling sites (seagrass, mangrove and beach ecosystems). On the other hand, low evenness $(E=0.5766)$ and dominance values $(D=$ 0.1399 ) in the island may indicate that only few species or perhaps no species dominate in the island, an indication that there is no competition of resources among the Echinoderm species in the island.

\section{Water physico-chemical parameters}

Based on the Water Quality Criteria of the Philippine Coastal and Marine Waters set by the Department of Environment and Natural Resources (DENR), all levels of the physico-chemical parameters such as the water temperature, $\mathrm{pH}$, salinity, and dissolved oxygen in all sampling sites in Manubul Island were found to be within the normal levels (Table 2). Although water temperature is one of the limiting factors that affects the abundance of Echinoderms (Walag \& Canencia, 2016), it is by no means the only exclusive factor, because there are some Echinoderm species (Protoreaster nodosus, Ophiocoma scolopendrina, Echinometra mathaei) that can only tolerate temperatures up to $35^{\circ} \mathrm{C}$ but not more than $40^{\circ} \mathrm{C}$ (Ubaldo et al., 2007). As for the water temperature of Manubul Island, values range from 28.33 to $28.98{ }^{\circ} \mathrm{C}$ which is considerably lower than the common temperature of marine water in tropical countries $\left(35^{\circ} \mathrm{C}\right)$.

On one hand, marine waters of Manubul Island had $\mathrm{pH}$ levels (7.83 to 8.18) which fall within the permissible $\mathrm{pH}$ range (6.0 to 8.5 ) set by the DENR. This level of $\mathrm{pH}$ indicates that the water body of the island is in basic condition, meaning the concentration of hydrogen ion is low and it is not acidic. Further, pH level lower than 4.5 is harmful to Echinoderms that affect the balancing of sodium and chloride in their circulatory systems. When sodium is depleted, hydrogen ions are taken into its cell causing death due to respiratory failure or the loss of regulation in osmotic pressure (Jacob, 2017).

The survival of Echinoderms in a particular habitat can be based according to their salinity tolerances (Russell, 2013). Thus, any change to salinity has the potential to affect their ability to perform vital biological processes, hence their ability to thrive and survive (Allen \& Pechenik, 2010). Manubul Island had salinity values ranging from 34.33 to 35 parts per thousand (ppt) which falls within the acceptable minimum level of salinity ( 35 ppt). The decrease value of salinity from 35 to 20 ppt can affect the burrowing behaviour of some Echinoderm species such as in the case of $H$. scabra (Mercier et al., 2000).

Meanwhile, the minimum level of dissolved oxygen (DO) for marine waters according to DENR 


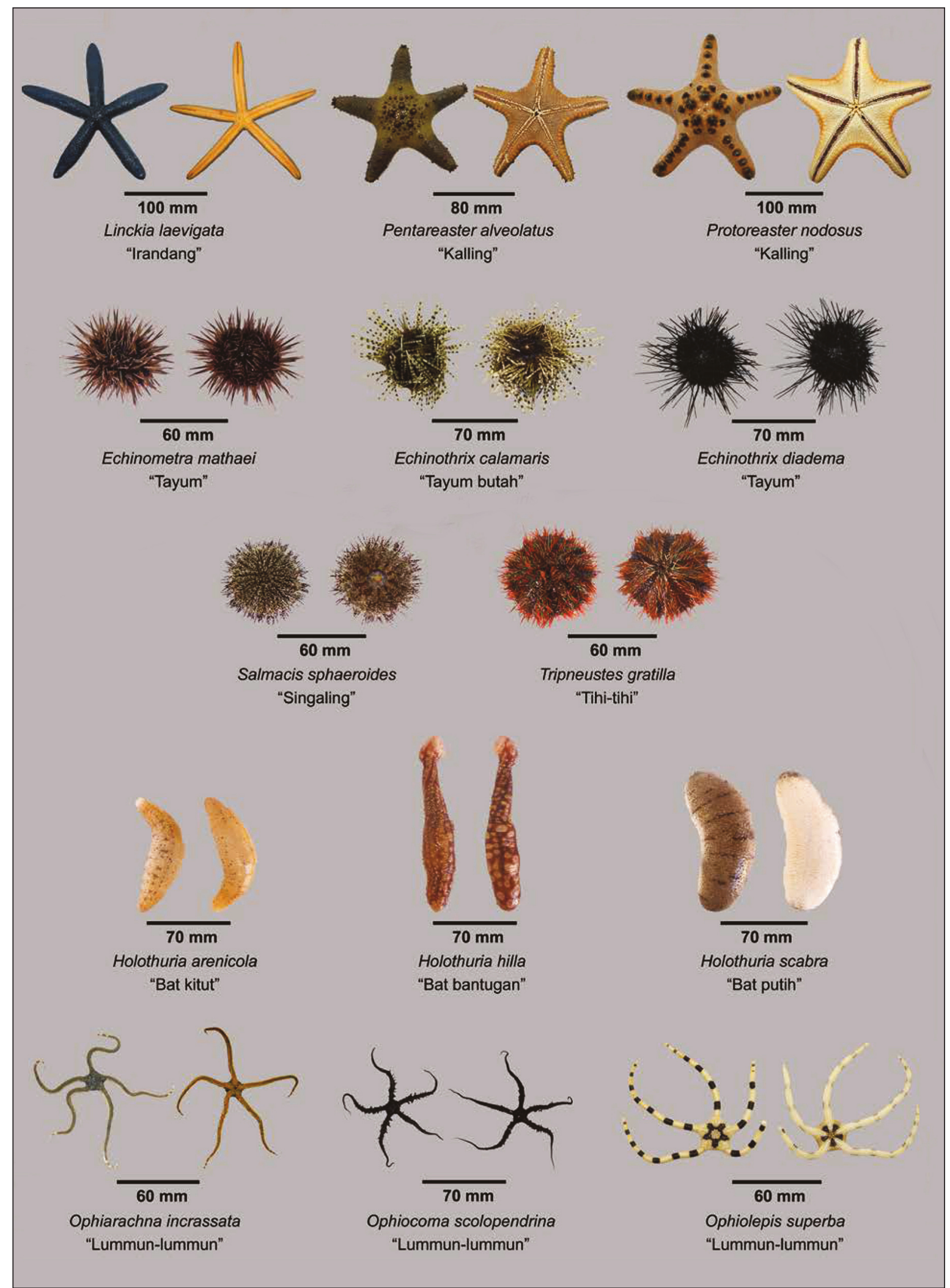

Figure 6. Echinoderms species with its local name in Manubul Island, Sulu, Province, Southern Philippines showing its aboral and oral view (dorsal and ventral view for sea cucumbers). 


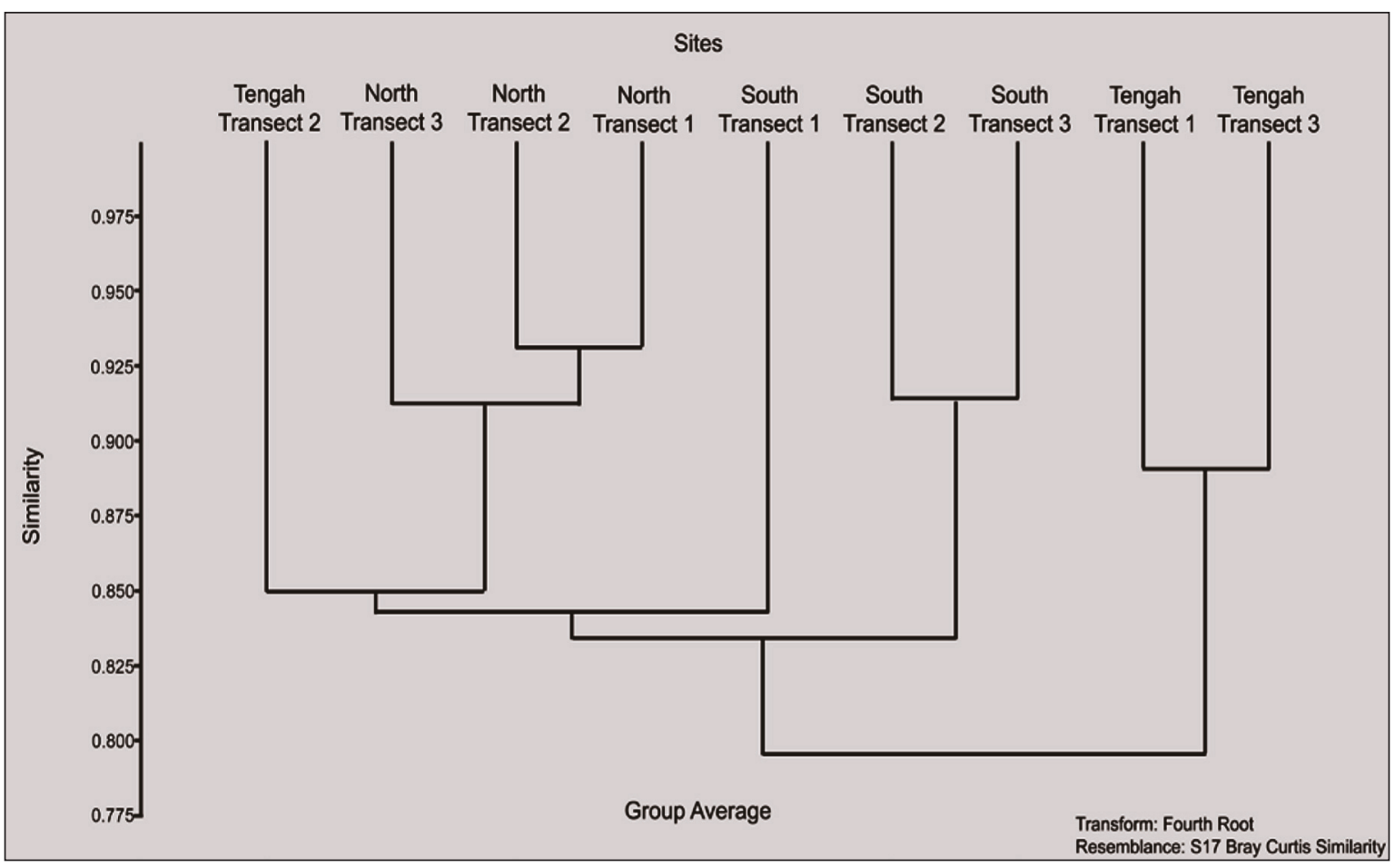

Figure 7. Cluster Analysis of Echinoderms community based on the abundance of the Echinoderms species using the Bray-Curtis similarity measure.

\begin{tabular}{|lccccc|}
\hline \multicolumn{1}{c}{ Study sites } & Species richness & Abundance & Dominance & Shannon & Evenness \\
\hline North Manubul & 13 & 879 & 0.1567 & 2.058 & 0.6024 \\
Tengah Manubul & 12 & 567 & 0.2295 & 1.781 & 0.4948 \\
South Manubul & 8 & 427 & 0.159 & 1.926 & 0.8581 \\
Manubul Island & $\mathbf{1 4}$ & $\mathbf{1 , 8 7 3}$ & $\mathbf{0 . 1 3 9 9}$ & $\mathbf{2 . 0 8 9}$ & $\mathbf{0 . 5 7 6 6}$ \\
\hline
\end{tabular}

Table 1. Diversity indices of Echinoderms in Manubul Island, Sulu Province, Southern Philippines.

should be $5 \mathrm{mg} / \mathrm{L}$ and it was observed that all of the sampling sites in the island had DO values ( 7.93 to $9.73 \mathrm{mg} / \mathrm{L}$ ) exceed the standard minimum value which could be attributed to the influence of photosynthesis, light intensity, and water temperature (Jack et al., 2009). Since oxygen is essential for the respiration of all marine organisms (Russell, 2013), this sufficient level of DO in the island of Manubul enables the Echinoderms to survive.

\section{CONCLUSIONS}

Our findings show that Manubul Island is a habitat of 14 Echinoderm species which are moderately diverse in the island, possibly due to habitat heterogeneity and normal water conditions of the island. However, this only provides a glimpse of the Echinoderm diversity in Sulu Province as there are still many islands in the province waiting for explorations. Further, this study highlights the need to regulate Echinoderm harvesting in the island, especially that there is one endangered Echinoderm species. We understand that there are limitations to our findings, for example, the coral reef ecosystem of the island was not included as sampling site due to time constrains and resources which may affect the species diversity in the island. 


\begin{tabular}{|c|c|c|c|c|}
\hline Study sites & $\begin{array}{c}\text { Temperature }\left({ }^{\circ} \mathrm{C}\right) \\
\text { Mean } \pm \text { SD }\end{array}$ & $\begin{array}{c}\mathbf{p H} \\
\text { Mean } \pm \text { SD }\end{array}$ & $\begin{array}{c}\text { Salinity (ppt) } \\
\text { Mean } \pm \text { SD }\end{array}$ & $\begin{array}{c}\text { D.O. }(\mathbf{m g} / \mathbf{L}) \\
\text { Mean } \pm \text { SD } \\
\end{array}$ \\
\hline \multicolumn{5}{|l|}{ North Manubul } \\
\hline Transect 1 & $28.98 \pm 0.37$ & $8.13 \pm 0.12$ & $35 \pm 0$ & $9.17 \pm 2.42$ \\
\hline Transect 2 & $28.74 \pm 0.50$ & $8.1 \pm 0.17$ & $35 \pm 0$ & $9.05 \pm 2.19$ \\
\hline Transect 3 & $28.62 \pm 0.03$ & $8.1 \pm 0.17$ & $34.67 \pm 0.58$ & $9.73 \pm 2.79$ \\
\hline Mean & $28.78 \pm 0.18$ & $8.11 \pm 0.02$ & $34.89 \pm 0.19$ & $9.32 \pm 0.36$ \\
\hline \multicolumn{5}{|l|}{ Tengah Manubul } \\
\hline Transect 1 & $28.65 \pm 0.35$ & $7.83 \pm 0.06$ & $34.43 \pm 0.98$ & $8.27 \pm 1.41$ \\
\hline Transect 2 & $28.63 \pm 0.85$ & $7.87 \pm 0.12$ & $34.53 \pm 0.50$ & $7.93 \pm 1.45$ \\
\hline Transect 3 & $28.75 \pm 0.79$ & $7.8 \pm 0$ & $35 \pm 0$ & $7.93 \pm 1.28$ \\
\hline Mean & $28.68 \pm 0.06$ & $7.83 \pm 0.04$ & $34.65 \pm 0.30$ & $8.04 \pm 0.20$ \\
\hline \multicolumn{5}{|l|}{ South Manubul } \\
\hline Transect 1 & $28.89 \pm 1.26$ & $8.13 \pm 0.12$ & $35 \pm 0$ & $7.94 \pm 1.10$ \\
\hline Transect 2 & $28.33 \pm 0.33$ & $8.2 \pm 0$ & $34.77 \pm 0.40$ & $8.21 \pm 1.80$ \\
\hline Transect 3 & $28.87 \pm 0.70$ & $8.2 \pm 0$ & $34.33 \pm 1.15$ & $8.38 \pm 1.59$ \\
\hline Mean & $28.70 \pm 0.32$ & $8.18 \pm 0.04$ & $34.73 \pm 0.29$ & $8.18 \pm 0.22$ \\
\hline
\end{tabular}

Table 2. Mean and standard deviation value on physico-chemical parameters of the three transects per sampling sites in Manubul Island, Sulu Province, Southern Philippines.

Further studies in the island and to the other neighbouring islands within Sulu Province are needed to provide a more comprehensive understanding on the biodiversity across the biogeographical province.

\section{ACKNOWLEDGEMENTS}

The authors would like to thank the Local Government Unit (LGU) of the municipality of Pandami, Sulu Province, Philippines, for allowing us to conduct this research in the locality as well as to the local fishermen for facilitating the first author during her sampling period. The offices of DENR-ARMM in Sulu, Philippines, and BFAR-Region IX in Zamboanga City, Philippines, are also acknowledged for providing the map of the study site and helping in identifying the Echinoderm species, respectively.

\section{REFERENCES}

Akamine J., 2005. Role of the trepang traders in the depleting resource management: A Philippine case. In:
Kishigami N. \& Savelle J.M. (Eds). Indigenous use and management of marine resources. Senri Ethnological Studies, 67: 259-278.

Alibon R.D. \& Madjos G.G., 2019. Bioecology of the Corallivorous Acanthaster planci (crown-of-thorns seastar) in the coastal areas of Dimataling, Zamboanga del Sur, Mindanao, Philippines, International Journal of Life Science, 7: 467-482.

Alibon R.D. \& Madjos G.G., 2020. Size structure and preyed corals of Acanthaster planci (crown-of-thorns seastar) in Lungui Island, Dimataling, Southern Philippines. Environmental and Experimental Biology, 8: 135-141. http.//doi:10.22364/eeb.18.13

Allen J.D. \& Pechenik J.A., 2010. Understanding the effects of low salinity on fertilization success and early development in the sand dollar Echinarachnius parma. Biology Bulletin, 218: 189-199. http.//doi: 10.1086/BBLv218n2p189

Balisco R.A., 2015. Notes on the Gracious Sea Urchin Tripneustes gratilla (Echinodermata: Echinoidea) in Pag-asa Island, Kalayaan, Palawan, Philippines. The Palawan Scientist, 7: 28-36.

Banlaoi R.C., 2008. The Abu Sayyaf Group and Terrorism in the Southern Philippines: Threat and Response." The US and the War on Terror in the Philippines. Abinales, Patricio and Nathan Gilbert Quimpo. Pasig City: Anvil. 
Bos A.R., Alipoyo J.C.E., Cardona L.T., Gumanao G.S. \& Salac F.N., 2008. Population structure of common Indo-Pacific sea stars in the Davao Gulf, Philippines. Proceedings of 9th Biannual Meeting Philippine Association of Marine Science. University of the Philippines in the Visayas Journal of Natural Science, p. 13.

Bureau of Fisheries and Aquatic Resources, 2013. Administrative Order No. 248 Series of 2013: Size regulation for sea cucumber collection and trade. (2013, December 4). The Philippine Star, p. B-13.

Choo P. 2008. The Philippines: a hotspot of sea cucumber fisheries in Asia. Sea Cucumbers. A Global Review of Fisheries and Trade (FAO Fisheries and Aquaculture Technical Paper), pp. 119-140.

Conand C. \& Gamboa R., 2013. Holothuria arenicola. The IUCN Red List of Threatened Species 2013:e.T180437A1630561.https://dx.doi.org/10.230 5/IUCN.UK.20131.RLTS.T180437A1630561.en. Retrieved from https://www.iucnredlist.org/species/ 180257/1606648.

Department of Environment and Natural Resources, 1990. Administrative Order No. 34 Series of 1990: Re-vised Water Usage and Classification/Water quality Criteria Amending Section No. 68 and 69, Chapter III of the 1978 NPCC Rules and Regulations. Retrieved from http://www.emb.gov.ph/laws/water $\% 20$ quality $\% 20$ management/dao90-34.pdf.

Frake C.O., 2006. The Cultural Construction of Rank, Identity and Ethnic Origins in the Sulu Archipelago. In: Fox J.J. \& Sather C. (Eds), Origins, Ancestry and Alliance. Explorations in Austronesian Ethnography, Canberra, pp. 319-332.

Hadfield M.G. \& Paul V.J., 2001. Natural chemical cues for the settlement and metamorphosis of marine invertebrate larvae. Pp. 431-461. In: McClintock J.G. \& Baker B.J (Eds.), Marine Chemical Ecology, CRC Press, Boca Raton, Fla, USA.

Hamel J.F., Mercier A., Conand C., Purcell S., ToralGranda T. G. \& Gamboa R., 2013. Holothuria scabra. The IUCN Red List of Threatened Species 2013: e.T180257A1606648.

https://dx.doi.org/10.2305/IUCN.UK.20131.RLTS.T180257A1606648.en. Retrieved from https://www.iucnredlist.org/species/ 180437/1630561.

Hammer Ø., Harper D.A.T. \& Ryan P.D., 2001. PAST: Paleontological Statistics Software Package for Education and Data Analysis. Palaeontologia Electronica, 4:

9. http://palaeo-electronica.org/2001_1/past/issue1 01.htm

Hereu B., Zabala M., Linares C. \& Sala E., 2005. The effects of predator abundance and habitat structural complexity on survival of juvenile sea urchins. Marine Biology, 146: 293-299.

Hernández J.C., Brito A., García N., Gil-Rodríguez M.
C., Herrera G., Cruz-Reyes A. \& Falcón M.J., 2006. Spatial and seasonal variation of the gonad index of Diadema antillarum (Echinodermata: Echinoidea) in the Canary Islands. Scientia Marina, 70: 689-698.

Jack J.P., Abdsalam A.T. \& Khalifa N.S., 2009. Assessment of dissolved oxygen in coastal waters of Benghazi, Libya. Journal of Black Sea/Mediterranean Environment, 15: 135-156.

Jacob S., 2017. How can a biological system be affected by a change in $\mathrm{pH}$ levels? Sciencing. Retrieved from https://sciencing.com/can-affected-change-ph-levels6165622.html.

Gamboa R., Gomez A.L. \& Nievales M.F., 2004. The status of sea cucumber fishery and mariculture in the Philippines. Pp. 69-78. In: Lovatelli A., Conand C., Purcell S., Uthicke S., Hamel J.F. \& Mercier A. (Eds.), Advances in sea cucumber aquaculture and management. FAO Fisheries Technical Paper. No. 463. Rome, 425 pp.

Jontila J.B.S., Balisco R.A.T. \& Matillano J.A., 2014. The sea cucumbers (Holothuroidea) of Palawan, Philippines. Aquaculture, Aquarium, Conservation \& Legislation- International Journal of the Bioflux Society, 7: 194-206.

Llacuna M.E.J., Walag A.M.P. \& Villaluz E.A., 2016. Diversity and dispersion patterns of echinoderms in Babanlagan, Talisayan, Misamis Oriental, Philippines. Environmental and Experimental Biology, 14: 213217. http://doi:10.22364/eeb.14.28

Londoño-Cruz E., Obonaga L.D. \& Zucconi-Ramírez M., 2018. First record of Echinothrix calamaris (Echinoidea: Diadematidae) in the Colombian Pacific. Marine Biodiversity Records, 11: 1-4. http://doi: 10.1186/s41200-018-0150-5

Mercier A., Battaglene S.C., Hamel J.F. 2000. Settlement preferences and early migration of the tropical sea cucumber Holothuria scabra. Journal of Experimental Marine Biology and Ecology, 249: 89-110. http://doi:10.1016/s0022-0981(00)00187-8

Murugan M., Rajendran N., Kasirajan S., Moorthy P., Balakrishnan G. 2016. Diversity assessment of echinoderms from Mudasalodai and Pazhayar in the southeast coast of India. Journal of Coastal Life Medicine, 4: 108-113. http://doi:10.12980/jclm.4.2016j5-156

Mamalangkap M.D., Mokamad U. K., Ayub S.M. 2018. Assessment of Small Pelagic Species Landed in ARMM, Sulu Sea. The Philippine Journal of Fisheries, 25: 183-192. http://doi:10.31398/tpjf/25.1.2017C0016

Nievales M.F.J., Juinio-Meñez M.A., Bangi H.G. 2006. Status and prospects of aquaculture of threatened echinoderms in the Philippines for stock enhancement and restocking. In: Primavera J.H., Quinitio E. T. \& Eguia M.R.R. (Eds.), Proceedings of the Re- 
gional Technical Consultation on Stock Enhancement for Threatened Species of International Concern, Iloilo City, Philippines, Tigbauan, Iloilo, Philippines: Aquaculture Department, Southeast Asian Fisheries Development Center, pp. 61-69. http://hdl.handle.net/10862/2934

Pawlik J.R., 1992. Chemical ecology of the settlement of benthic marine invertebrates. Oceanography and Marine Biology, An Annual Review, 30: 273-335.

Peleo A., 2015. Secure in insecurity: The case of threat perception/acceptance in the Philippines. Cogent Social Sciences, 1: 1060687. https://doi.org/10.1080/23311886.2015.1060687

Pitogo K.M.E., Sumin J.P. \& Ortiz A.T., 2018. Shallowwater Sea Cucumbers (Echinodermata: Holothuroidea) in Sarangani Bay, Mindanao, Philippines with Notes on Their Relative Abundance. Philippine Journal of Science, 147: 453-461.

Purcell S.W., Samyn Y. \& Conand C., 2012. Commercially important sea cucumbers of the world. FAO Species Catalogue for Fishery Purposes. No. 6. Rome, $150 \mathrm{pp}$.

Purcell S.W., Mercier A., Conand C., Hamel J.F., Toral-Granda M.V., Lovatelli A. \& Uthicke S., 2013. Sea cucumber fisheries: global analysis of stocks, management measures and drivers of overfishing. Fish and Fisheries, 14: 34-59. http://doi.10.1111/j.1467-2979.2011.00443.x

Raghunathan C. \& Venkataraman K., 2012. Diversity of echinoderms in Rani Jhansi Marine National Park, Andaman and Nicobar Islands. International Day for Biological Diversity, Marine Biodiversity. UttarPradesh State Biodiversity Board, 36-48.

Regalado J.M., Campos W.L. \& Santillan A.S., 2010. Population Biology of Tripneustes gratilla (Linnaeus) (Echinodermata) in seagrass beds of Southern Guimaras, Philippines. Science Diliman, 22: 41-49.

Russell M.P., 2013. Echinoderm Responses to Variation in Salinity. Advances in Marine Biology, 66: 71-212.

Scheibling R.E. \& Metaxas A. 2010. Mangroves and fringing reefs as nursery habitats for the endangered Caribbean sea star Oreaster reticulatus. Bulletin of Marine Science, 86: 133-148.

Schoppe S., 2000. Echinoderms of the Philippines: a guide to common shallow water sea stars, brittle stars, sea urchins, sea cucumbers and feather stars. VISCA-GTZ Program on Applied Tropical Ecology, Visayas State College of Agriculture, Philippines.

Schwarz A.M., Morrison M., Hawes I. \& Halliday J., 2006. Physical and biological characteristics of a rare marine habitat: sub-tidal seagrass beds of offshore is- lands. Science for Conservation 269. Department of Conservation, Wellington, p. 39.

Stöhr S., O'Hara T.D. \& Thuy B., 2012. Global diversity of brittle stars (Echinodermata: Ophiuroidea). Public Library of Science One, 7: e31940. https://doi.org/10.1371/journal.pone.0031940

Tabugo S.M., Pattuinan J.O., Sespene N.J. \& Jamasali A.J., 2013. Some Economically Important Bivalves and Gastropods found in the Island of Hadji Panglima Tahil, in the province of Sulu, Philippines. International Research Journal of Biological Science, 2: 3036.

Toral-Granda V., 2006. Summary of FAO and CITES Workshops on sea cucumbers: major findings and conclusions. Convention on international trade in endangered species of wild fauna and flora. Twentysecond meeting of the animals committee, Lima, Peru,p 5.

Tubelis D.P. \& Cavalcanti R.B., 2001. Community similarity and abundance of bird species in open habitats of a Central Brazilian Cerrado. Ornitologia Neotropical, 12: 57-73.

Ubaldo J.P., Uy F.A. \& Dy D.T., 2007. Temperature tolerance of some especies of Philippine intertidal echinoderms. Philippine Journal of Science, 44: 105119. http://doi:10.3860/psci.v44i0.381

United Nations. 2019. Security Council Press Statement on Terrorist Attack in Sulu Province, Philippines. Retrieved from https://www.un.org/press/en/2019/sc 13681.

Walag A.M.P. \& Canencia M.O.P., 2016. Physico-chemical parameters and macrobenthic invertebrates of the intertidal zone of Gusa, Cagayan de Oro City, Philippines. Advances in Environmental Science Bioflux, 8: 71-82.

Walag A.M.P., del Rosario R.M. 2018. Proximate Biochemical Composition and Brine Shrimp Lethality Assay Of Selected Sea Stars From Goso-On And Vinapor, Carmen, Agusan del Norte, Philippines. Malaysian Journal of Biochemistry and Molecular Biology, 3: 11-18.

Wolkenhauer S.M., Uthicke S., Burridge C., Skewes T. \& Pitcher R., 2010. The ecological role of Holothuria scabra (Echinodermata: Holothuroidea) within subtropical seagrass beds. Journal of the Marine Biological Association of the United Kingdom, 90: 215-223. http://doi:10.1017/S0025315409990518

Yokota Y., 2002. Introduction to the sea urchin biology. Pp. 1-10. In: Yokota Y., Matranga V. \& Smolenicka Z. (Eds.), The Sea Urchin: From Basic Biology to Aquaculture, Balkema, Lisse, The Netherlands. 
